\title{
Calculation of the differences of attitude and behavior of two generations with the Euclidian-metric
}

\author{
Daniela SERBAN \\ The Bucharest University of Economic Studies, Bucharest, Romania \\ danielaserban2011@gmail.com \\ Corina PELAU \\ The Bucharest University of Economic Studies, Bucharest, Romania \\ corina.pelau@fabiz.ase.ro \\ Alexandra Catalina CHINIE \\ The Bucharest University of Economic Studies, Bucharest, Romania \\ alexandra.chinie@fabiz.ase.ro
}

\begin{abstract}
This paper presents the results of a research about the differences of behavior between two generations. Pairs of consumers consisting of a young consumer and one of his/her parents were questioned about different aspects of life. By applying the Euclidian Metric, the similarities and differences were determined for the examined issues. The results of the research show that for traditional product groups like medical services, education system, the consumers of the two generations have a similar behavior. For product groups related to the online environment such as social networks, mobile/ smart phones, the consumers of the two generations show higher differences. Higher differences can be also observed for social groups, as the young generation has an inclination for doing spare time activities with their friends, such as going out, going on holiday. The results of the research have an impact on the way in which consumer's reference groups are going to be used in marketing communication campaigns.
\end{abstract}

Keywords: consumer behavior, reference groups, generation, perception.

\section{Introduction}

Each generation has its own characteristics depending on the political, economic and social environment in which people were raised and educated. According to Williams and Page (2010) a generation is "a group of persons who travel through life together and experience the same events at a similar age" (Williams, Page 2010). Based on the context in which each generation has lived, it developed its own behavior, perceptions, beliefs and attitudes. According to marketers it is important to know the set of perceptions, believes, attitudes and behavior typologies of each generation in order to be able to target them in a better way. Therefore several studies about the characteristics of each generation as "consumers" have been done in order to develop specific marketing strategies for each of the generations.

According to different sources six categories of generations were defined for the US: the pre-depressions, the depressions, the baby-boomers, the $\mathrm{X}$ generation, the $\mathrm{Y}$ generation and the $Z$ generation (Dietz 2003). Ordun (2015) defines three categories of generations for Bulgaria: the post war generation (born until 1965), the communist generation (born between 1965 and 1980), the democracy generation (born after 1980) (Ordun 2015). A similar division of generations can be observed in Romania. There can be a discussion about 
the existence of a fourth type of generation as the democracy generation can be split in the early democracy generation of people who lived in the transition period and the new democracy generation of children born after 2005, with parents being educated in the democracy generation.

Regarding the $\mathrm{Y}$ generation, researchers agree to the fact that it has its own distinctions because it is the generation of the computer and internet era (Hyllegard, Yan et. al. 2011). In opposition to older generations of the $20^{\text {th }}$ century, they are the consumers who grew up with new technologies and consequently with access to more information, increased communication and a higher mobility (Neuborne 1999). This access to information, technology and social networks makes it as one of the most influential generations (Childers, Rao 1992).

One aspect regarding this distinctive generation is the influence of the reference groups on the consumer behavior. It is known that older generation "learned" many of their living and consumption patterns from their parents, as in their time the access to media was reduced. In opposition to the older generation, the young consumers have access to different media, interact much more with the social group consisting out of friends and colleagues and therefore the influence of the family diminishes. Therefore it is interesting to study which is the influence of the different social groups and of the media on the young generation of consumers. Depending on this influence, business should adapt their marketing strategies (Solomon, Bamossy, et.al. 2010).

\section{Methodology and coordinates of the research}

The objective of this research is to determine the influence of the parents as a reference group on the behaviour of the young consumers. The research tries to highlight the activities done by children and parents in a similar way, and those which are done differently. In order to determine these, a research was conducted in which both groups, the young consumers and their parents were questioned on the same issues. The questionnaire contained besides the demographic elements, 70 Likert-scale questions with affirmations about the everyday behaviour and perceptions of the respondents. These questions were answered by both the young consumers and their parents. The sample of the research contained 120 pairs of consumers (a pair made by a young consumer and one of his/her parent) from the urban population in Romania, leading to 240 questioned persons. The research took place in the period November-December 2015.

In order to determine the differences between the behaviour of the two groups, the mean perceptions were calculated for each group and the difference between the two means was tested. The higher the values of the difference, the smaller are the similarities of the two groups. As the indicator is calculated as the difference between the average perceptions of the students towards the items minus the average perception of the parents towards the same issues, the plus sign indicates a higher appropriateness of the item towards the young generation, while the minus sign indicates that the items best describes the behaviour of the parents.

Another indicator used to measure the similarities of behaviour and perception of

the two generations is an adapted Euclidian Metric Indicator (Euclidian Distance). This indicator is calculated as follows: 


$$
\begin{aligned}
& \mathrm{d}_{\mathrm{i}}=\left[\sum_{r=1}^{120}\left(p_{A r}-p_{B r}\right)^{2}\right]^{\frac{1}{2}} \\
& \mathrm{~d}_{\mathrm{i}}=\text { distance between items } \\
& \mathrm{r}=\text { number of the respondent } \\
& \mathrm{p}_{A \mathrm{r}}=\text { perception of respondent } \mathrm{r} \text { from group A (the young generation) } \\
& \mathrm{p}_{\mathrm{Br}}=\text { perception of respondent } \mathrm{r} \text { from group B (the parents) }
\end{aligned}
$$

The smaller the Euclidian Distance is, the smaller are the differences between the two groups. Higher Euclidian Distances also indicate higher differences in the behaviour.

\section{Interpretation of the results}

Results of the analysis are presented in Table 1, consisting of the mean of the items for the young generation (mean A), the mean of the items for their parents (mean B) and the difference between the two means and the Euclidian Metric/ Distance. The results are sorted after the Euclidian Metric having the items with similar perceptions at the beginning and the items with higher differences at the end.

One area in which the young generation and their parents have similar behaviour and perceptions is the medical field. Although there is a similar behaviour for the medical services, the generation of the parents has a slow inclination in the preference towards the public medical system (item 1), while the young generation tends to prefer the private healthcare system (item 5). Despite these, both generations prefer the private medical services over the public hospitals. A similar behaviour is for choosing the doctor, where the parents' generation prefers to go to the doctors they know (item 6). Another group of items with similar behaviour for the two generation are the way in which they shop. So both groups prefer to do shopping in the big retail chains (item 2).

The importance and impact of graduating a university is another aspect where the young generations and their parents have a similar perception. They believe that graduating a university leads to a better position in the society (item 7), but their belief is weaker in the sense that the image of a university has an impact on the social position (item 17). While the young generation rather agrees that graduating a university has an impact on the social position (item 7), in the case of item 17, the parents rather agree to it. It is also interesting to observe that the young generation rather believes that the position at the job is more important than the salary (item 11).

There are average differences in the behaviour regarding the holiday, depending upon the analysed issues. The young generation affirms that they go once a year on vacation (item 14). It is an affirmation with over average means for both generations. The generation of the parents seems to prefer to go on vacation with the partner/family (item 16) and prefers Romania as destination (item 12). None of the generations is very fond of exotic destinations (item 25), neither prefers expensive hotels (item 8), although there is an inclination of the young generation towards it especially for the exotic destinations. An item where the difference between the young generation and their parents differs is the option of going on vacation with friends which young people stated that they prefer, more than older people (item 38).

As mentioned before both generations go shopping to big retail chains (item 2). There is an average distance for the type of products the two generations buy. The young 
generation is rather open to trying new products, while the older generation prefers the product they know (item 22, item 23). Another item for which the behaviour differs is the timeframe for shopping, as most of the consumers do shopping when they need something (item 4). It is interesting to remark that the generation of parents rather do shopping in advance (item 30), although it is a type of behaviour which characterize them having an under average mean. One behaviour which differs is the convenience of buying products on the internet which is typical for the young generation (item 36). The type of clothing they wear, are also behaviours which are rather alike. Wearing casual cloths (item 13), bought from known stores (item 18) or from the internet (item 21) are behaviours which are rather typical for the young generation and are not too similar and not to different from their parents.

The type of ownership shows differences in perception and behaviour depending on the type of product. Although none of the generations drives an expensive car, the behaviour is more typical for the parents' generation (item 3) which can probably afford an expensive car, more than younger generations do. Having modern electronic equipment is a behaviour typical for the young generation (item 10). Living in a home owned by the family is, as expected, a behaviour which characterizes the parents' generation, as they have the financial means to afford their own home (item 37). In opposition to these, the young generation live in a flat (item 41) or in a rented apartment (item 45). All items regarding the accommodation are rather different for the two generations.

The spare time activities differ also from one generation to the other. While the generation of the parents prefer to spend their spare time with the family (item 24) and they eat most of the meals at home (item 31), the young generation prefers to go out with their friends (item 42), to go to the mall or to the movies (item 40). They also eat more often their meals out (item 28) and they go shopping with their friends (item 29).

Another aspect which differs from one generation to the other is constituted of the payment methods. While the generation of the parents prefers the classic cash payment (item 20), the young one use more and more modern electronic payment methods (item 27).

Table 1. Results of the research

\begin{tabular}{|c|c|c|c|c|c|}
\hline & Item & $\begin{array}{c}\text { Mean } \\
\text { A }\end{array}$ & $\begin{array}{c}\text { Mean } \\
\text { B }\end{array}$ & $\begin{array}{l}\text { Difference } \\
\text { (A - B) }\end{array}$ & $\begin{array}{l}\text { Euclidian } \\
\text { Metric }\end{array}$ \\
\hline 1 & I trust more in the public healthcare system & 2.38 & 2.83 & -0.45 & 13.04 \\
\hline 2 & $\begin{array}{l}\text { I do shopping in the big retail chains (like } \\
\text { hypermarket) }\end{array}$ & 4.18 & 4.01 & 0.18 & 13.15 \\
\hline 3 & I can afford to drive an expensive car & 2.42 & 2.65 & -0.23 & 14.07 \\
\hline 4 & I buy every day the products I need & 2.99 & 2.80 & 0.19 & 14.25 \\
\hline 5 & I prefer the private medical clinics & 3.91 & 3.50 & 0.41 & 14.53 \\
\hline 6 & $\begin{array}{l}\text { I choose a doctor and I get an appointment no } \\
\text { matter if he works in a public or a private clinic }\end{array}$ & 3.70 & 3.82 & -0.12 & 14.90 \\
\hline 7 & $\begin{array}{l}\text { Graduating an university has an impact on the } \\
\text { social position }\end{array}$ & 4.13 & 4.04 & 0.09 & 15.07 \\
\hline 8 & I buy at least twice a week half-cooked products & 3.06 & 2.58 & 0.48 & 15.20 \\
\hline 9 & $\begin{array}{l}\text { On vacation I get accommodation at a four star } \\
\text { hotel }\end{array}$ & 2.82 & 2.68 & 0.14 & 15.52 \\
\hline 10 & $\begin{array}{l}\text { It is important for me, to have modern electronic } \\
\text { equipment }\end{array}$ & 3.77 & 3.50 & 0.27 & 15.62 \\
\hline 11 & $\begin{array}{l}\text { The position at work is more important than the } \\
\text { salary }\end{array}$ & 3.14 & 2.88 & 0.27 & 15.68 \\
\hline
\end{tabular}




\begin{tabular}{|c|c|c|c|c|c|}
\hline 12 & I prefer to spend my holiday in Romania & 2.93 & 3.68 & -0.75 & 15.93 \\
\hline 13 & I prefer to wear casual cloths & 3.24 & 3.12 & 0.13 & 16.16 \\
\hline 14 & I go at least once a year on vacation & 4.13 & 3.81 & 0.33 & 16.52 \\
\hline 15 & I prefer business clothes & 3.03 & 3.03 & 0.00 & 16.61 \\
\hline 16 & $\begin{array}{l}\text { I usually go on vacation with my partner or } \\
\text { family }\end{array}$ & 3.83 & 4.45 & -0.62 & 16.79 \\
\hline 17 & $\begin{array}{l}\text { Only by graduating a university, one can make a } \\
\text { career }\end{array}$ & 3.28 & 3.66 & -0.38 & 17.12 \\
\hline 18 & I wear clothes from well-known shops & 3.52 & 3.03 & 0.49 & 17.97 \\
\hline 19 & Applications can be more easily used on tablets & 3.25 & 2.52 & 0.73 & 18.22 \\
\hline 20 & I prefer the classic cash payment method & 3.06 & 3.53 & -0.48 & 18.30 \\
\hline 21 & I buy clothing products on the internet & 2.83 & 1.89 & 0.93 & 18.49 \\
\hline 22 & $\begin{array}{l}\text { I am open and I try the new products on the } \\
\text { market }\end{array}$ & 3.88 & 3.04 & 0.83 & 18.55 \\
\hline 23 & I rather buy the products I know & 3.43 & 3.97 & -0.53 & 18.55 \\
\hline 24 & I prefer to spend my spare time with my family & 3.33 & 4.38 & -1.05 & 18.81 \\
\hline 25 & On vacation I go the exotic destinations & 3.21 & 2.88 & 0.33 & 18.84 \\
\hline 26 & $\begin{array}{l}\text { In the city, I prefer the public transportation } \\
\text { means }\end{array}$ & 2.84 & 2.67 & 0.18 & 18.89 \\
\hline 27 & $\begin{array}{l}\text { I use more and more the electronic payment } \\
\text { means (card, internet) }\end{array}$ & 3.86 & 3.06 & 0.80 & 18.97 \\
\hline 28 & I eat in the city at least three times a week & 3.22 & 2.35 & 0.87 & 19.08 \\
\hline 29 & I go often with my friend shopping & 2.93 & 2.02 & 0.91 & 19.47 \\
\hline 30 & I do the shopping for the next $1-2$ weeks & 2.98 & 3.65 & -0.67 & 19.70 \\
\hline 31 & I eat the important meals at home & 3.05 & 3.95 & -0.90 & 19.80 \\
\hline 32 & I work in the field I have studied & 3.36 & 3.73 & -0.37 & 20.25 \\
\hline 33 & $\begin{array}{l}\text { My most important transportation mean is my } \\
\text { car }\end{array}$ & 3.38 & 3.78 & -0.40 & 20.74 \\
\hline 34 & I like to play games on the computer & 2.80 & 1.68 & 1.12 & 21.07 \\
\hline 35 & I use the computer/ laptop only at work & 2.58 & 2.98 & -0.41 & 21.14 \\
\hline 36 & $\begin{array}{l}\text { Online shopping is more convenient than classic } \\
\text { ones }\end{array}$ & 3.35 & 2.33 & 1.03 & 21.61 \\
\hline 37 & $\begin{array}{l}\text { I live in a home, which is my/ my family's } \\
\text { property }\end{array}$ & 3.58 & 4.20 & -0.63 & 21.61 \\
\hline 38 & I prefer to go with my friends on holiday & 3.78 & 2.70 & 1.08 & 21.93 \\
\hline 39 & I use the internet to get the news of the day & 4.33 & 3.07 & 1.26 & 22.20 \\
\hline 40 & $\begin{array}{l}\text { I go often with my friend to the mall, to the } \\
\text { movies or bowling }\end{array}$ & 3.21 & 1.74 & 1.47 & 22.58 \\
\hline 41 & I live in a flat & 3.73 & 3.47 & 0.26 & 22.87 \\
\hline 42 & $\begin{array}{l}\text { I spend my spare time going out with friends in } \\
\text { restaurants or cafes }\end{array}$ & 3.53 & 2.02 & 1.51 & 23.26 \\
\hline 43 & $\begin{array}{l}\text { I permanently connected to the internet through } \\
\text { my mobile phone }\end{array}$ & 4.31 & 2.81 & 1.50 & 23.66 \\
\hline 44 & I prefer smart-phones & 4.75 & 3.16 & 1.59 & 23.77 \\
\hline 45 & I live in a rented apartment & 2.49 & 1.39 & 1.10 & 24.64 \\
\hline 46 & I have account on most of the social networks & 4.15 & 2.19 & 1.96 & 27.26 \\
\hline
\end{tabular}

Source: Authors' own results.

The biggest differences in the behaviour and perception of the two generations are the modern electronic and digital means of communication. In opposition to the generation of the parents, the young consumers have accounts on most of the social networks (item 46), they prefer smart-phones (item 44) and they are permanently connected to the internet through several devices (item 43). They also use the internet in order to obtain the 
daily news (item 39) and they also play games on the computer (item 34). On the other side the generation of the parents rather uses the computer at work and rarely at home (item 35).

\section{Conclusions}

In an analysis of the influence of reference groups on the young consumer, it can be affirmed the fact that the parents still have a big influence on their children behaviour as consumers. There are of course branches in which the influence is higher and other where the influence is smaller. As it can be observed in the classic fields when it comes to health issues or education the perceptions and behaviours are more similar. One explanation for this is that parents usually invest in the education of their children and therefore they try in a conscious way to influence their children' behaviour. The behaviour related to the medical services is a key aspect for the health of each individual and therefore the young generations tend to imitate the behaviour of the reference group they trust most and these are the parents. Consequently it can be observed that in two major aspects the consumer tend to have the same behaviour as their parents.

The behaviour of the two generations of consumers towards shopping or going on vacations, are also similar, but a bit more different than the previous presented. This can be explained by the fact that these are types of behaviours which are imitated in an unconscious way. No parent tries to teach his children how to go shopping or where to go on vacation. But still, by doing these activities together, some of the behaviour patterns are taken over in an unconscious way by the young generations. Another aspect is the fact that some of these activities might be financed by the parents, fact that influences the behaviour of the young consumers.

A type of behaviour for which the differences between the young generations and their parents are higher, is the acceptance of modern electronic payment methods and the clothes they wear. In the case of the cloths, there is an obvious change of trends which determine the young generations to buy more and more casual clothes, while the older generations tend to buy clothes which were fashionable in their youth time. Another aspect is related to the payment methods, where the young generations are rather willing to use them in their shopping behaviour.

The activities with the highest differences for the two generations are the spare time activities and the usage of modern electronic equipment. It is known that all young people tend to spend their spare time with their friends and each generation has its own novelty activities. Therefore the activities for the free time, for the young generation and their parents are different. The same happens with the usage of modern electronic equipment as the young generation has a higher capacity of learning how to use them, and therefor uses more frequently equipment like laptops, tablets or smart-phones. Consequently the differences in the behaviour related to their parents are higher.

Knowing who influences a certain category or generation of consumers is very helpful to marketing research, as communication campaigns can be more easily developed. A company can develop its strategy according to the expectations of the target group, only by knowing the attitudes and beliefs of the target consumer's generation. Especially the analysis of the young generation is important as it is the generation of the future and as mentioned before it is more and more different compared to previous generations. 


\section{References}

Backhaus, K., Erichson, B., Plinke, W., Weiber, R. (2000). Multivariate Analysemethoden - Eine anwendungsorientierte Einfuehrung, Springer, Berlin.

Childers Terry L., Rao, Akshay R. (1992).The Influence of Familial and Peer-Based Reference Groups on Consumer Decisions, in: Journal of Consumer Research, 19(2), 198-211.

Dawn B.V., Powers, T.L. (2013). Generation Y values and lifestyle segments, Journal of Consumer Marketing, 30 (7), 597-606.

Dietz, J. (2003). Defining Markets, Defining Moments - America's 7 Generational Cohorts, Their Shared Experiences and Why Business Should Care, in: The Journal of Consumer Marketing, $20(2 / 3), 172-174$.

Drake-Bridges, E. and Burgess, B. (2010). "Personal preferences of tween shoppers", Journal of Fashion Marketing and Management, 14(4), 624-633.

Furlow, N.E. (2011). "Find us on Facebook: how cause marketing has embraced social media", Journal of Marketing Development and Competitiveness, Vol. 5 No. 6, pp. 61-64.

Hyllegard, K. , Yan, R., Ogle, J. and Attmann, J. (2011). "The influence of gender, social cause, charitable support, and message appeal on Gen Y's responses to cause-related marketing", Journal of Marketing Management, 27 (1/2), 100-123.

Istudor, N.; Pelau, C. (2012). Changes in the consumer behavior depending on gender, in Bratianu, C.; Lixandroiu, D.; Pop, N. Al.: Business Excellence - Challenges during the Economic Crisis, Proceedings of the 6th International Conference on Business Excellence, Brasov, pg. 249-253.

Kroeber-Riel, W., Weinberg P. (2003). Konsumentenverhalten, Vahlen, München, 2003.

Neuborne, E. (1999), “Generation Y”, Business Week, 36(16), 80-88.

Noble, S.M., Haytko, D.L. and Phillips, J. (2009), "What drives college-age Generation Y consumers?”, Journal of Business Research, 62(6), 617-628.

Ordun, G. (2015). Millennial (Gen Y) Consumer Behavior, Their Shopping Preferences and Perceptual Maps Associated with Brand Loyalty, in: Canadian Social Sciences, 11(4), 40-55.

Solomon, M., Bamossy, G., Askegaard, S., Hogg, M.K. (2010). Consumer Behavior - A European Perspective, 4th edition, Prentice Hall, Financial Times, Harlow.

Williams, K.C.; Page, R.A. (2010). Marketing to Generations, in: Journal of Behavioral Studies in Business, 3, April 2011. 